\title{
Genetic Variability Study in Fennel (Foeniculum valgare Mill)
}

\author{
D.G. Patel, H.B. Patel*, Chauhan Surbhi and A.M. Patel
}

Seed Spices Research Station, S.D. Agricultural University, Jagudan-382710, Gujarat, India

*Corresponding author

\section{A B S T R A C T}

Sixteen genotypes of fennel were evaluated at Main Seed Spices Research Station, S. D. Agricultural University, Jagudan, Gujarat during rabi 2015-16, for estimates of variability,

Keywords

Coefficient of variation, Fennel, Genetic advance, Heritability

Article Info

Accepted:

18 October 2018

Available Online:

10 November 2018 heritability and genetic advance in eight quantitative traits, viz., plant height, number of branches per plant, days to $50 \%$ flowering, days to maturity, number of umbels per plant, number of umbelletes per umbel, number of seeds per umbellete and seed yield per plant. The analysis of variance indicated that presence of considerable amount of diversity in the material. Phenotypic coefficients in variations were of higher magnitude than that of genotypic coefficient of variations for all the traits. The highest GCV and PCV were observed for seed yield per plant (25.14 and $26.97 \%$ ) and number of umbels per plant (15.85 and $17.72 \%$ ). High estimates of heritability was observed for days to maturity (96.89\%), days to $50 \%$ flowering $(93.02 \%)$, seed yield per plant $(86.90 \%)$, plant height $(85.29 \%)$ and umbels per plant $(80.06 \%)$ and it was recorded medium for number of branches per plant $(46.79 \%)$ and number of umbelletes per umbel $(28.62 \%)$. High heritability coupled with high genetic advance as percentage of mean for traits like seed yield per plant and number of umbels per plant which indicated that higher response for selection to high yields as these characters are governed by additive gene actions.

\section{Introduction}

Fennel (Foeniculum vulgare Mill) belongs to family Apiaceae and its seed are used as spice. Fennel is widely cultivated throughout the temperate and subtropical regions. Gujarat rank first in area, production and productivity of fennel. Fennel is used in a wide range of curry powder, curries flavoured soups, such as mulligatanny and shorbas, and is often used with fish. Fennel seeds are also used in pickles, chicken casseroles, salad dressings, fish liver and pork sauces and cucumber, sauerkraut lentils and pickled beef. Powdered fennel goes into biscuits, cakes and cooked apple dishes. Fennel is considered as one of the minor spices, since its quantity and value is much smaller compared to other spices.

Though many improved varieties of fennel have been released in the country, there are still ample scope for crop improvement by traditional and advanced methods of breeding to increase the adaptability and productivity of the crop.

\section{Materials and Methods}

The experiment was conducted at Seed Spices Research Station, S. D. Agricultural 
University, Jagudan during rabi 2015-16. Sixteen genotypes of fennel collected from different part of the country were grown in a randomized block design with three replications. The seeds of fennel genotypes were sown with a spacing of $45 \times 20 \mathrm{~cm}$ and recommended cultural practices were followed. The observations were recorded on eight quantitative characters on five randomly selected plants of each genotype in each replication. The data were subjected to statistical analysis as per the method described by Panse and Sukhatme (1961). The variance components and coefficient of variance determined according to Burton (1952). The heritability (broad sense) was calculated using formula proposed by Hanson et al., (1956) and expected genetic advance was worked out by Johnson et al., (1955).

\section{Results and Discussion}

The mean squares due to genotypes were highly significant for all the characters indicating that the presence of genetic diversity in the material (Table 1) Agnihotri et al., (1997) reported that the same findings in fennel. The maximum plant height was recorded in genotypes FNL-80 $(185.93 \mathrm{~cm})$ and it was minimum in RF-205 $(133.80 \mathrm{~cm})$. Branches per plant exhibited maximum in genotypes FNL-77 (7.40). Genotype Rf- 205 (6.87) and FNL-78 (6.40) which were at par, while, the lowest (5.13) branches per plant were recorded in FNL-81 and FNL-89. The maximum 24.07 and 22.33 number of umbels per plant was recorded in genotypes FNL-77 and FNL-78 respectively, while; it was lowest in genotype FNL-89 (14.00). Umbellets per umbel were recorded maximum in FNL-77 (26.07) and it was found minimum in FNL-89 (18.93). Genotype FNL-40 gave the maximum (30.93) number of seeds per umbellete, while it was observed minimum in RF-205 (C) (24.00). The early $50 \%$ flowering was noted in FNL-77 and GF-12 (91.67 days) and late 50\% flowering was observed in FNL-85 (108.33 days). Early maturity was observed in FNL-77 (152.0 days) and late maturity was observed in FNL-86 and FNL-86 (168.00 days). Significantly highest $34.69 \mathrm{~g}$ seed yield per plant were recorded in genotypes FNL-77. Whereas, FNL-85 produced minimum seed yield (14.89 g/plant). These finding are in agreement with the finding of Singh et al., (2003), Dashora et al., (2011), Patel et al., (2008) and Sengupta et al., (2014)

Phenotypic coefficients in variations were of higher magnitude than that of genotypic coefficient of variations for all the traits showing that the environment had an important role in influencing the expression of the traits. The phenotypic and genotypic coefficient of variations ranged from $3.36 \%$ for days to maturity to $36.97 \%$ for seed yield per plant. The highest phenotypic and genotypic coefficient of variation was observed for seed yield per plant (36.97 and $25.14 \%)$, number of umbels per plant (17.72 and $15.85 \%$ ). However it was found to be medium for the characters like number of branches per plant (13.98 and $9.56 \%)$, number of umbelletes per umbel (12.60 and $6.74 \%)$ and plant height (10.45 and $9.65 \%)$ (Table 2). The remaining characters were exhibited low phenotypic coefficient of variation. These findings are close conformity with findings of Rajput et al., (2004), Sengupta et al., (2014) and Patel et al., (2015).

High estimates of heritability (broad sense) was exhibited for days to maturity (96.89\%) followed by days to $50 \%$ flowering $(93.02 \%)$, seed yield per plant $(86.90 \%)$, plant height $(85.29 \%)$ and number of umbels per plant (80.06 \%). However, it was recorded to be medium for number of branches per plant (46.79 \%). High values of broad sense heritability for the above characters, expressed that they were least influenced by environmental modification. 
Table.1 Analysis of variance for nine characters of Fennel (Mean squares)

\begin{tabular}{|l|c|c|c|c|c|c|c|c|c|c|}
\hline $\begin{array}{l}\text { Source of } \\
\text { variation }\end{array}$ & d.f. & $\begin{array}{c}\text { Plant height } \\
\text { (cm) }\end{array}$ & $\begin{array}{c}\text { No. of } \\
\text { branches / } \\
\text { plant }\end{array}$ & $\begin{array}{c}\text { Days to } \\
\text { fo\% } \\
\text { flowering }\end{array}$ & $\begin{array}{c}\text { Days to } \\
\text { maturity }\end{array}$ & $\begin{array}{c}\text { Umbels/ } \\
\text { plant }\end{array}$ & $\begin{array}{c}\text { Umbellet } \\
\text { s/ } \\
\text { umbel }\end{array}$ & $\begin{array}{c}\text { No. of } \\
\text { seeds / } \\
\text { Umbellet }\end{array}$ & $\begin{array}{c}\text { Seed yield/ } \\
\text { Plant(g) }\end{array}$ \\
\hline Replications & 2 & 181.466 & 0.941 & 0.1458 & 4.000 & 1.143 & 4.981 & 16.616 & 30.587 \\
\hline Genotypes & 15 & $789.868^{* *}$ & $1.285^{*}$ & $93.466^{* *}$ & $86.098^{* *}$ & $28.000^{* *}$ & $12.818^{*}$ & $10.738^{*}$ & $116.569^{* *}$ \\
\hline Error & $\mathbf{3 0}$ & 42.956 & 0.353 & 2.2792 & 0.911 & 2.147 & 5.818 & 4.900 & 5.578 \\
\hline
\end{tabular}

\begin{tabular}{|c|c|c|c|c|c|c|c|c|}
\hline \multicolumn{9}{|c|}{ Table.2 Mean performance of various parameters of fennel (Foeniculum vulgare Mill.) } \\
\hline Genotypes & $\begin{array}{l}\text { Plant } \\
\text { height } \\
\text { (cm) }\end{array}$ & $\begin{array}{l}\text { No. of } \\
\text { branches / } \\
\text { plant }\end{array}$ & $\begin{array}{l}\text { Days to } \\
\mathbf{5 0 \%} \\
\text { flowering }\end{array}$ & $\begin{array}{l}\text { Days to } \\
\text { maturity }\end{array}$ & $\begin{array}{l}\text { Umbels/ } \\
\text { plant }\end{array}$ & $\begin{array}{l}\text { Umbellets/ } \\
\text { umbel }\end{array}$ & $\begin{array}{l}\text { No. of } \\
\text { seeds / } \\
\text { Umbellet }\end{array}$ & $\begin{array}{l}\text { Seed } \\
\text { yield/ } \\
\text { Plant(g) }\end{array}$ \\
\hline FNL-77 & 154.67 & 7.40 & 91.67 & 152.00 & 24.07 & 26.07 & 28.80 & 34.69 \\
\hline FNL-78 & 141.80 & 6.40 & 94.67 & 155.67 & 22.33 & 23.40 & 26.80 & 30.24 \\
\hline FNL-79 & 166.07 & 6.27 & 96.00 & 155.33 & 22.13 & 25.13 & 28.93 & 29.51 \\
\hline FNL-80 & 171.53 & 6.00 & 100.33 & 160.33 & 18.87 & 24.60 & 24.80 & 25.54 \\
\hline FNL-81 & 185.93 & 5.13 & 102.67 & 162.67 & 17.13 & 22.87 & 28.73 & 21.03 \\
\hline FNL-82 & 174.93 & 5.67 & 102.67 & 161.33 & 18.67 & 22.20 & 30.93 & 27.71 \\
\hline FNL-83 & 167.33 & 5.33 & 106.33 & 166.00 & 17.00 & 21.67 & 26.40 & 21.24 \\
\hline FNL-84 & 176.87 & 5.67 & 104.67 & 165.00 & 15.60 & 21.40 & 27.73 & 18.83 \\
\hline FNL-85 & 170.20 & 5.67 & 108.33 & 167.67 & 14.20 & 20.27 & 28.13 & 14.89 \\
\hline FNL-86 & 184.80 & 5.00 & 108.00 & 168.00 & 15.00 & 21.60 & 24.40 & 16.17 \\
\hline FNL-87 & 163.67 & 5.93 & 102.67 & 161.33 & 18.33 & 21.60 & 27.47 & 22.74 \\
\hline FNL-88 & 158.67 & 5.27 & 103.67 & 163.33 & 16.93 & 20.53 & 28.67 & 20.10 \\
\hline FNL-89 & 177.00 & 5.13 & 108.00 & 168.00 & 14.00 & 18.93 & 27.67 & 15.17 \\
\hline RF-201 (NC) & 155.20 & 5.87 & 96.67 & 156.67 & 20.93 & 22.00 & 26.00 & 28.43 \\
\hline RF-205 (NC) & 133.80 & 6.87 & 100.67 & 159.33 & 21.07 & 25.60 & 24.00 & 30.65 \\
\hline GF-12 (LC) & 134.40 & 5.67 & 91.67 & 152.33 & 20.07 & 24.60 & 28.87 & 30.11 \\
\hline SEm \pm & 3.78 & 0.34 & 0.87 & 0.55 & 0.85 & 1.39 & 1.28 & 1.36 \\
\hline C.D. at $5 \%$ & 10.93 & 0.99 & 2.52 & 1.59 & 2.44 & 4.02 & 3.69 & 3.94 \\
\hline
\end{tabular}

\begin{tabular}{|c|c|c|c|c|c|c|c|c|}
\hline \multicolumn{9}{|c|}{ Table.3 Genetic parameters in Fennel (Feoniculum vulgare Mill.) } \\
\hline \multirow[t]{2}{*}{$\begin{array}{l}\text { S. } \\
\text { No. }\end{array}$} & \multirow[t]{2}{*}{ Characters } & \multirow[t]{2}{*}{$\begin{array}{l}\text { Grand } \\
\text { mean }\end{array}$} & \multicolumn{2}{|c|}{ Range } & \multicolumn{2}{|c|}{$\begin{array}{c}\text { Coefficient of } \\
\text { variation }\end{array}$} & \multirow[t]{2}{*}{$\begin{array}{l}\text { Heritability (\%) } \\
\text { (Broad sense) }\end{array}$} & \multirow{2}{*}{$\begin{array}{c}\text { Genetic } \\
\text { advance } \\
\text { as \% of } \\
\text { mean }\end{array}$} \\
\hline & & & Min. & Max. & $\begin{array}{l}\text { Geno- } \\
\text { typic }\end{array}$ & $\begin{array}{l}\text { Pheno- } \\
\text { typic }\end{array}$ & & \\
\hline 1. & Plant height (cm) & 163.55 & 128.0 & 197.2 & 9.65 & 10.45 & 85.29 & 18.35 \\
\hline 2. & No. of branches per plant & 5.83 & 4.8 & 8.4 & 9.56 & 13.98 & 46.79 & 13.47 \\
\hline 3. & Days to $50 \%$ flowering & 101.67 & 91.0 & 108.0 & 5.44 & 5.65 & 93.02 & 10.83 \\
\hline 4. & Days to maturity & 160.94 & 151.0 & 170.0 & 3.31 & 3.36 & 96.89 & 6.71 \\
\hline 5. & No. of umbels per plant & 18.52 & 12.2 & 25.2 & 15.85 & 17.72 & 80.06 & 29.21 \\
\hline 6. & No. of Umbellets per umbel & 22.65 & 17.8 & 28.8 & 6.74 & 12.60 & 28.62 & 7.43 \\
\hline 7. & No. of seeds per umbellet & 27.40 & 22.2 & 33.2 & 5.09 & 9.55 & 28.42 & 5.59 \\
\hline 8. & Seed yield/plant (g) & 24.19 & 13.0 & 37.0 & 25.14 & 26.97 & 86.90 & 48.28 \\
\hline
\end{tabular}

It reflected that the phenotypes were the true representative of their genotypes and selection based on phenotypic performance would be reliable. The highest estimate of genetic advance as percentage of mean was recorded for seed yield per plant $(48.28 \%)$ and number of umbels per plant $(29.21 \%)$. While, it was recorded medium for plant height $(18.35 \%)$ and branches per plant (13.47\%) (Table 3). Rest of the characters showed the low genetic advance 
as percentage of mean. The results were in close proximate to that of Sharma et al., (2015) and Meena et al., (2013). High heritability coupled with high genetic advance as percentage of mean for traits like seed yield per plant and number of umbel per plant. Suggested that the preponderance of additive genes. It also indicated higher response for selection to high yields as these characters are governed by additive gene actions. The results were in closing proximate to that of Mehta and Patel (1985). High estimates of heritability coupled with moderate expected genetic advance as percentage of mean have been observed for plant height which might be attributed to additive gene action conditioning their expression and phenotypic selection for their amenability can be brought about. High heritability associated with low estimates of genetic advance as percentage of mean was observed for days to $50 \%$ flowering and days to maturity. This revealed the predominance of non-additive gene action in the expression of these characters. These findings are close conformity with findings of Rajput et al., (2004), Sengupta et al., (2014) and Singh et al., (2003).

\section{References}

Burton G.W. (1952). Quantitative inheritance in grasses. Proc. 6th Int. Grassland Cong. 1: 227-285.

Dashora, A. and Sastry, E.V.D. (2011). Variability, character association and path coefficient analysis in fennel. Indian Journal of Horticulture. 6: 55-57.

Hanson C.H., Robinson H.F. and Comstock R.E. (1956). Biometrical studies of yield in segregating population of Korean Lespedsa. Agron. J. 48: 268-272.
Johnson H.W., Robinson H.F. and Comstock R.E. (1955). Estimates of genetics and environment variability in soybean. Agron. J. 47: 314-318.

Meena, S.K., Singh, B. and Meena, A.K. (2013). Variability in fennel (Foeniculum vulgare Mill.) for yield and yield attributes. Journal of Genetics and Biotech. 5 (2): 117-124.

Panes V.G. and Sukhatme P.V. (1961). Statistical methods for Agricultural workers, ICAR, New Delhi.

Patel, D.G., Patel, P.S. and Patel, I.D. (2008). Studies on variability of some morphological characters in fennel. Journal of Spices and Aromatic Crops. 19: 29-32.

Patel, Y.N. and Patel, M.P. (2015). Studies of Genetic Variability, Correlation, Heritability and Genetic Advance in Fennel (Foeniculum vulgare Miller). Published in Trends in Biosciences. 8 (3): pp. 823-826.

Rajput S.S., Singhania D.L., Singh D., Sharma K.C. and Rathore V.S. (2004). Assessment of genetic variability in fennel (Foeniculum vulgare Mill). Published in National Seminar on New Perspective in Commercial Cultivation Processing and Marketing of Seed Spices and Medicinal Plants held at S.K.N. College of Agriculture, Jobner, p 10.

Sengupta, S.K., Verma, B.K. and Naidu, A.K. (2014). Genetic Variability Study in Fennel (Foeniculum vulgare Mill.). International Science Journal. 1 (1): 36-38.

Sharma, L.K., Meena, R.S. and Panwar A. (2015). Genetic variability on yield and its yield attributing characters in fennel (Foeniculum vulgare Mill.). Published In: International Journal of Seed Spices. 5 (1): pp. 95-97.

Singh Yudhvir., Mittal Pankaj and Katoch Viveka (2003). Evaluation of fennel (Foeniculum vulgare Mill) genotypes under mid-hill humid sub-temperate conditions. Himachal J. Agri. Res. 29 (1\&2): 48-51.

\section{How to cite this article:}

Patel, D.G., H.B. Patel, Chauhan Surbhi and Patel, A.M. 2018. Genetic Variability Study in Fennel (Foeniculum valgare Mill). Int.J.Curr.Microbiol.App.Sci. 7(11): 2403-2406. doi: https://doi.org/10.20546/ijcmas.2018.711.273 